This article is licensed under the Creative Commons Attribution-NonCommercial 4.0 International License (CC BY-NC) (http://www.karger.com/Services/OpenAccessLicense). Usage and distribution for commercial purposes requires written permission.

\title{
Multiloculated Cavitary Primary Pulmonary Hodgkin Lymphoma: Case Series
}

\author{
Yasser Aljehani $^{a} \quad$ Hind Al-Saif $^{b} \quad$ Aisha Al-Osail ${ }^{c} \quad$ Emad Al-Osail $^{d}$ \\ a'Division of Thoracic Surgery, Department of General Surgery, King Fahd University \\ Hospital, College of Medicine, Imam Abdulrahman Bin Faisal University, Al-Khobar, \\ Saudi Arabia; ${ }^{b}$ Department of Radiology, King Fahd University Hospital, College of \\ Medicine, Imam Abdulrahman Bin Faisal University, Al-Khobar, Saudi Arabia; \\ 'Department of Internal Medicine, King Fahd University Hospital, College of Medicine, \\ Imam Abdulrahman Bin Faisal University, Al-Khobar, Saudi Arabia; ${ }^{\mathrm{d}}$ General Surgery \\ Department, King Fahad Military Medical Complex, Dhahran, Saudi Arabia
}

\section{Keywords}

Cavitary lesion · Hodgkin lymphoma · Primary pulmonary Hodgkin lymphoma

\begin{abstract}
Primary pulmonary Hodgkin lymphoma (PPHL) is very rare and typically involves the superior portion of the lung. Pulmonary involvement is observed in $15-40 \%$ of Hodgkin lymphoma patients. Three such patients who presented with an unusual form of PPHL in radiological studies, i.e., multiloculated cavitary lesions, were admitted to our hospital. These lesions represent a new pathological and radiological feature of PPHL.




\section{Case Reports in Oncology}

\section{Introduction}

Primary pulmonary Hodgkin lymphoma (PPHL) is a rare tumor, but reports of this malignancy have become more frequent in recent years. Pulmonary manifestations of Hodgkin lymphoma (HL) are usually characterized by a single nodule, multiple nodules, a single cavitary lesion or a mass. However, the patients described herein presented with multiloculated cavitary lesions, which are a very rare radiological manifestation. The aim of this report is to add to the current literature and examine possible correlations with other differentials in this geographical area.

\section{Case 1}

A 16-year-old male presented with fever, weight loss, and a productive cough for several weeks. On examination, his temperature was $39.5^{\circ} \mathrm{C}$, and decreased air entry and fine crepitation in the right middle zone were observed. The laboratory tests indicated a white blood cell (WBC) count of 35,000/ $\mu \mathrm{L}$. His erythrocyte sedimentation rate (ESR) was 120 $\mathrm{mm} / \mathrm{h}$ and his C-reactive protein (CRP) level was $15 \mathrm{mg} / \mathrm{dL}$. The blood culture and acid fast bacilli (AFB) stain were negative. A chest X-ray (CXR) showed a large cavity lesion with a smooth margin and a thickened wall with air fluid levels associated with adjacent lung consolidation that involved the right middle and lower lung zones silhouetting the cardiac border. An enhanced chest CT scan showed a large multiloculated cavitary lesion that involved the right middle lobe and the anterior mediastinum, with internal air and fluid. Some reactive mediastinal lymph nodes were observed (Fig. 1). Video-assisted thoracoscopy (VATS) was performed due to the inconclusive nature of the CT-guided biopsy. Bronchoalveolar lavage (BAL) cytology was negative for malignant cells. The histopathology was consistent with classic HL nodular sclerosing type disease, and the immunohistochemistry was positive for CD30, CD68, CD3, CD20, and LCA but negative for CD15 and CK.

The patient was referred to an oncology service for further management.

\section{Case 2}

A 29-year-old female diagnosed with bronchial asthma presented with a dry cough that converted to a purulent productive cough for several weeks. She subsequently experienced episodes of hemoptysis. Her physical examination was unremarkable. Her initial WBC count was $8.4 \mathrm{k} / \mu \mathrm{L}$. ESR was $84 \mathrm{~mm} / \mathrm{h}$ and her CRP was $5.5 \mathrm{mg} / \mathrm{dL}$. A septic workup indicated that all cultures and an AFB stain were negative. Her CXR showed a cavitary lesion involving the right middle zone of the lung. An enhanced chest CT scan showed a $4.4 \times 4.6 \times 6.3 \mathrm{~cm}$ mass with central hypodensity indicating a multiloculated cavitary lesion, and air was observed at the right anterior mediastinum and anterior segment of the right upper lobe. Moreover, enlarged reactive lymph nodes were observed along the prevascular space and para-aortic region (Fig. 2a, b). The patient underwent a CT-guided biopsy, and the histopathology was 


\section{Case Reports in Oncology}

consistent with nodular sclerosing type HL. The immunohistochemistry was positive for CD30, CD15, and CD3 with CD20 lymphocytes.

The patient was referred to an oncology service for further management.

\section{Case 3}

A 21-year-old male diagnosed with hypothyroidism and sickle cell anemia presented with fever and a productive cough for 4 months. He indicated a history of night sweats and weight loss. On examination, right anterior $3 \times 3 \mathrm{~cm}$ cervical swelling was palpable. The thyroid gland was slightly enlarged. A chest examination demonstrated bilateral decreased air entry over the middle and lower zones. His initial WBC count was $14.2 \mathrm{k} / \mu \mathrm{L}$. His CRP was 5.8 $\mathrm{mg} / \mathrm{dL}$ and his ESR was $120 \mathrm{~mm} / \mathrm{h}$. A septic workup indicated that all cultures and AFB staining were negative. The CXR showed a diffuse heterogeneous opacity in the right middle zone. An enhanced chest CT scan showed a large mass extending from the anterior aspect of the mediastinum with an intrapulmonary component measuring $11 \times 9 \times 12 \mathrm{~cm}$ and a necrotic center. The thick enhancing soft tissue rim indicated a multiloculated cavitary lesion (Fig. 3a, b). Moreover, the echocardiogram showed pericardial effusion. The CT-guided biopsy was consistent with classic nodular sclerosing type HL, and the immunohistochemistry was positive for CD30 and CD15 but negative for CD45, CD3, and CD20. He was referred to an oncology service for further treatment.

Table 1 shows a complete summary of all cases.

\section{Discussion}

HL is a type of malignancy that originates from B lymphocytes and spreads through and to lymph node groups or organs outside lymphatic system. In 1832, Thomas Hodgkin reported 6 cases of primary lymph node tumors [1]. He was the first to describe lymph system abnormalities in a paper titled "On some morbid appearances of the absorbent glands and spleen” [2]. In 1898 and 1902, Carl Sternberg and Dorthy Reed Mendenhall discovered giant cells in tissues of patients with HL, currently known as Reed-Sternberg cells [3]. Wolpaw et al. [4], Stolberg et al. [5], and Sheinmel et al. [3] subsequently described the radiology and pathology of HL characterized by Reed-Sternberg cells [5, 6]. Despite the descriptive nature of these papers, they provide a useful foundation to study HL. Subsequently, Macdonald [7] collected data from 284 patients diagnosed with HL in Nottingham from 1960 to 1975 and found that $43 \%$ had lung involvement. The most common radiographic type was peribronchial infiltration, which occurs in the early stage of the disease, whereas less common types, such as homogeneous or pneumonic infiltrates or nodules, usually occur later in the disease process. Radin [8] examined 60 cases of PPHL and reported that this disease was predominant in younger women. Between 1990 and 2003, 7 new cases of PPHL were described, and 5 additional cases were subsequently described in 2006 [9]. Specifically, a report from 1998 describes 3 cases of PPHL, 2 of which exhibited unilateral upper lobe cavitary lesions, and 1 exhibited bilateral lower lobe nodules [10]. Moreover, a study from India reported a thickwalled single cavitary lesion in the left upper zone with areas of necrosis observed on radio- 
graphs [11]. Our experience and reports from Saudi Arabia indicate 2 reported cases of PPHL, and radiological studies showed pulmonary parenchymal masses [12].

Pulmonary involvement occurs in $15-40 \%$ of HL cases [13] and may be caused by peribronchiolar adenopathies near the pulmonary parenchyma or a significant amount of lymphoid follicles [14]. Pulmonary HL usually manifests as a single nodule, multiple nodules, a single cavitary lesion or a mass. However, we herein describe an unusual radiological feature - a multiloculated cavitary lesion. The differential diagnosis of cavitary lesions is complex and includes infectious causes, such as pulmonary Gram-negative bacteria, actinomycosis, histoplasmosis or aspergillosis, pneumonia, abscesses, pulmonary TB, hydrated cysts, or septicemic emboli. Moreover, these lesions may be due to a malignancy, such as squamous cell carcinoma, sarcomas, osteosarcomas or a metastasis to the lung. Nevertheless, this condition may also be attributed to granulomatous diseases, such as Wegener granulomatosis $[13,15,16]$.

Because of this complexity, all patients underwent noninvasive and invasive testing. A septic workup excluded infectious disease, and this conclusion was supported by a lack of response to antibiotic therapy in cases 1 and 2. The chest CT scans of all patient showed enlarged reactive mediastinal lymph nodes, which may be attributed to the disease, a reaction to a parenchymal infection within the cavity or a pneumonic reaction. Considering the geographical origin of these cases, this presentation is usually due to an infective cause, but lymphoma should be considered as a cause, especially in young females.

\section{Conclusion}

Based on a literature review and our limited experience, we recommend that PPHL be included in the differential diagnosis of any cavitary pulmonary single or multiloculated lesion, especially in young females.

\section{Statements of Ethics}

The authors have no ethical conflicts to disclose.

\section{Disclosure Statement}

The authors have no conflicts of interest to declare.

\section{Funding Sources}

No funding was received for this work. 


\section{References}

1 Fox H. Remarks on the presentation of microscopical preparations made from some of the original tissue described by Thomas Hodgkin, 1832. Ann Med Hist. 1926;8:370-4.

2 Stone MJ. Thomas Hodgkin: medical immortal and uncompromising idealist. Proc Bayl Univ Med Cent. 2005 Oct;18(4):368-75.

3 Sheinmel A, Roswit B, Lawrence LR. Hodgkin's disease of the lung; roentgen appearance and therapeutic management. Radiology. 1950 Feb;54(2):165-79.

4 Wolpaw SE, Higley CS, Hauser H. Intrathoracic Hodgkin's disease. Am J Roentgenol. 1944;52:374-87.

5 Stolberg HO, Patt NL, Macewen KF, Warwick OH, Brown TC. Hodgkin's disease of the lung. Roentgenologicpathologic correlation. Am J Roentgenol Radium Ther Nucl Med. 1964 Jul;92:96-115.

6 Sturn A, Quackenbush J, Trajanoski Z. Genesis: cluster analysis of microarray data. Bioinformatics. 2002 Jan;18(1):207-8.

7 Radin AI. Primary pulmonary Hodgkin's disease. Cancer. 1990 Feb;65(3):550-63.

8 MacDonald JB. Lung involvement in Hodgkin's disease. Thorax. 1977 Dec;32(6):664-7.

9 Rodriguez J, Tirabosco R, Pizzolitto S, Rocco M, Falconieri G. Hodgkin lymphoma presenting with exclusive or preponderant pulmonary involvement: a clinicopathologic study of 5 new cases. Ann Diagn Pathol. 2006 Apr;10(2):83-8.

10 Cartier Y, Johkoh T, Honda O, Müller NL. Primary pulmonary Hodgkin's disease: CT findings in three patients. Clin Radiol. 1999 Mar;54(3):182-4.

11 Chauhan A, Gupta K, Mullick S, Agarwal S. Primary pulmonary Hodgkin's lymphoma: two case reports. J Case Rep. 2014;4(2):348-51.

12 Tillawi IS. Primary pulmonary Hodgkin's lymphoma. A report of 2 cases and review of the literature. Saudi Med J. 2007 Jun;28(6):943-8.

13 Fuentes Pradera J, Arriola Arellano E, Miguel Cisneros J, Quiroga E. Adenopatías mediastínicas y masa pulmonar cavitada como forma de presentación de la enfermedad de Hodgkin. Med Clin (Barc). 2001 Oct; 117(10):398-9.

14 Bakan ND, Camsari G, Gur A, Ozkan G, Bayram M, Gorgulu F et al. A 21-year-old male with productive cough, hemoptysis, chest pain, and weight loss. Respiration. 2007;74(6):706-9.

15 Lachanas E, Tomos P, Fotinou M, Kalokerinou K. An unusual pulmonary cavitating lesion. Respiration. 2005 Nov-Dec;72(6):657-9.

16 Bataller R, Urbano-Ispizua A, Luburich P, Montserrat E, Rozman C. [Pulmonary cavitation as the initial manifestation of Hodgkin's disease]. Med Clin (Barc). 1994 Sep;103(9):342-3. 


\section{Case Reports in Oncology}

Aljehani et al.: Multiloculated Cavitary Primary Pulmonary Hodgkin Lymphoma:

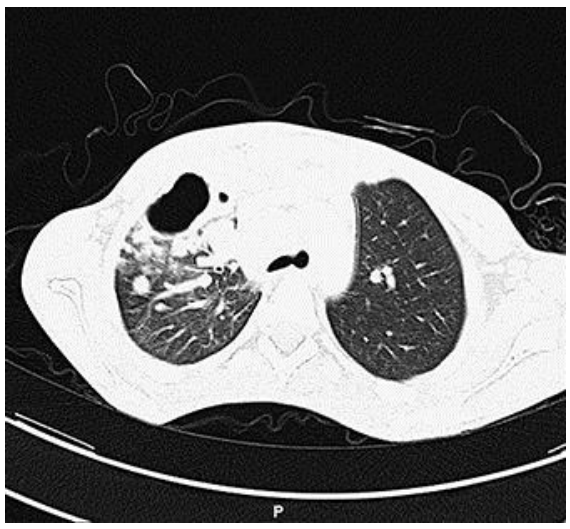

Fig. 1. Enhanced chest CT scan axial cut (pulmonary window) showing a large multiloculated cavity lesion involving the right middle lobe and the anterior mediastinum with internal air and fluid.
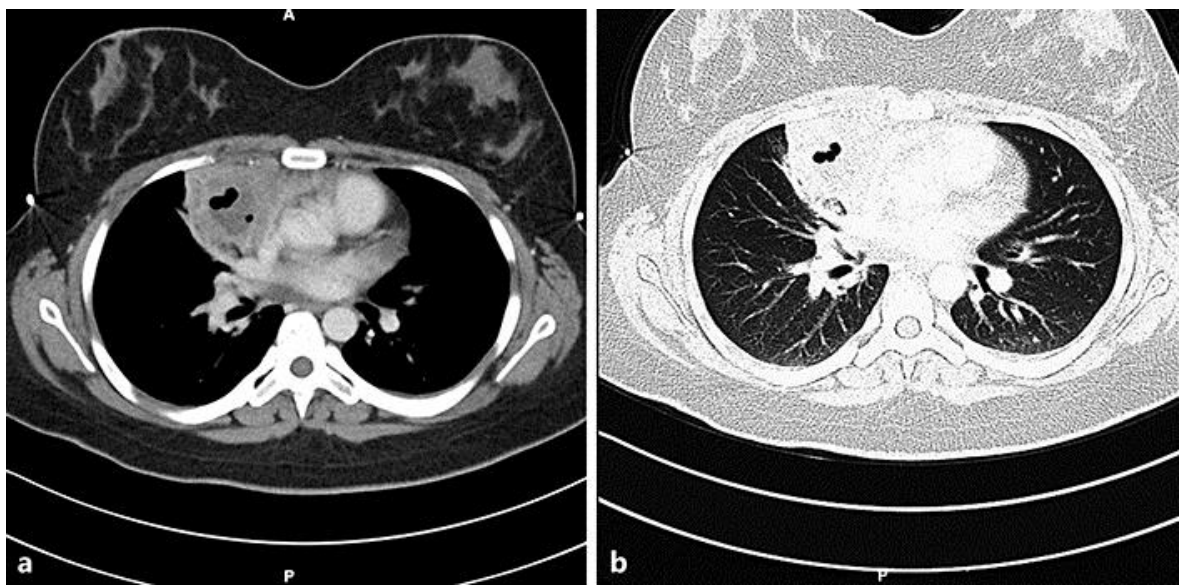

Fig. 2. a CT scan of the chest mediastinal window. b CT scan of the chest lung window. 


\section{Case Reports in Oncology}
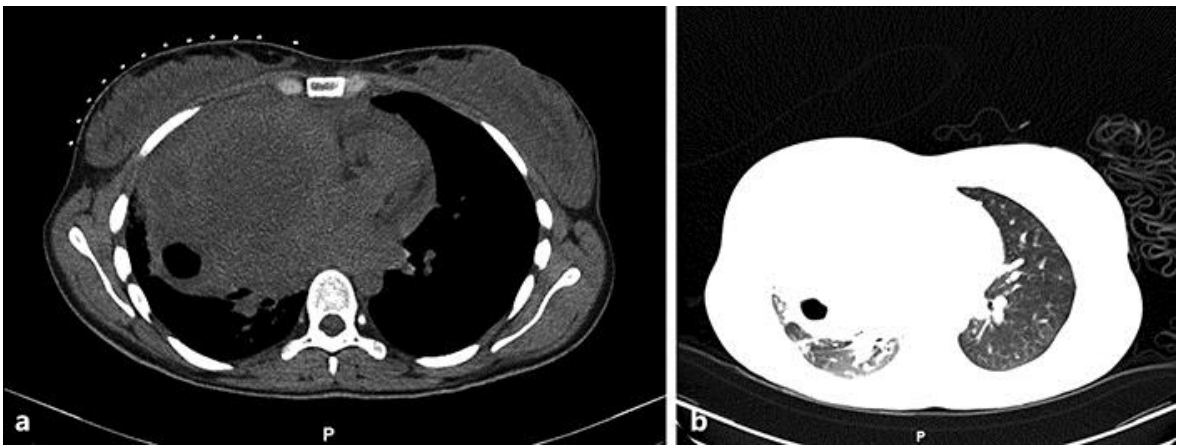

Fig. 3. a CT scan of the mediastinal window. b CT scan of the lung window. 


\section{Case Reports in Oncology}

Aljehani et al.: Multiloculated Cavitary Primary Pulmonary Hodgkin Lymphoma:

Table 1. Case summary

\begin{tabular}{|c|c|c|c|}
\hline & Patient 1 & Patient 2 & Patient 3 \\
\hline Age, years & 16 & 29 & 21 \\
\hline Gender & Male & Female & Female \\
\hline Presenting complain & $\begin{array}{l}\text { fever } \\
\text { weight loss } \\
\text { productive cough }\end{array}$ & $\begin{array}{l}\text { productive cough } \\
\text { hemoptysis }\end{array}$ & $\begin{array}{l}\text { fever } \\
\text { night sweat } \\
\text { weight loss }\end{array}$ \\
\hline $\begin{array}{l}\text { Labs (abnormal } \\
\text { results) }\end{array}$ & 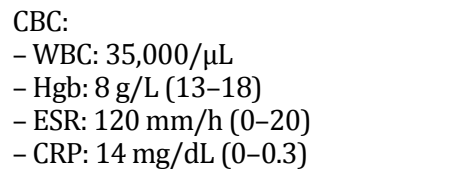 & $\begin{array}{l}\text { CRP: } 5.5 \mathrm{mg} / \mathrm{dL} \\
\text { ESR: } 84 \mathrm{~mm} / \mathrm{h}\end{array}$ & $\begin{array}{l}\text { CBC: } \\
\text { - Hgb: } 9.2 \mathrm{~g} / \mathrm{L} \\
\text { - CRP: } 5.8 \mathrm{mg} / \mathrm{dL} \\
\text { - ESR: } 120 \mathrm{~mm} / \mathrm{h}\end{array}$ \\
\hline Chest X-ray & $\begin{array}{l}\text { large cavitary lesion with smooth } \\
\text { margins and thickened walls; air } \\
\text { fluid levels associated with adjacent } \\
\text { lung consolidation involving the } \\
\text { right middle and lower lung zones } \\
\text { silhouetting the cardiac border }\end{array}$ & $\begin{array}{l}\text { cavitary lesion involving the right mid } \\
\text { zone of the lung }\end{array}$ & $\begin{array}{l}\text { diffuse heterogeneous opacity } \\
\text { occupying the right middle } \\
\text { zones with evidence of a cavity }\end{array}$ \\
\hline CT scan & $\begin{array}{l}\text { large multiloculated cavitary lesion } \\
\text { involving the right middle lobe and } \\
\text { the anterior mediastinum with } \\
\text { internal air and fluid; some reactive } \\
\text { mediastinal lymph nodes were } \\
\text { observed }\end{array}$ & $\begin{array}{l}4.4 \times 4.6 \times 6.3 \mathrm{~cm} \text { mass with central } \\
\text { hypodensity indicating a multiloculated } \\
\text { cavitary lesion; air was observed in the } \\
\text { right anterior mediastinum and anterior } \\
\text { segment of the right upper lobe; } \\
\text { enlarged reactive lymph nodes were } \\
\text { observed along the prevascular space } \\
\text { and along the para-aortic region }\end{array}$ & $\begin{array}{l}\text { large mass extending from } \\
\text { the anterior aspect of the } \\
\text { mediastinum with an } \\
\text { intrapulmonary component } \\
\text { measuring } 11 \times 9 \times 12 \mathrm{~cm}, \\
\text { necrotic center and thick } \\
\text { enhancing soft tissue rim } \\
\text { indicating a multiloculated } \\
\text { cavitary lesion }\end{array}$ \\
\hline Biopsy source & mediastinal lymph node & mediastinal lymph node & cervical lymph node \\
\hline $\begin{array}{l}\text { Methods of biopsy } \\
\text { taking }\end{array}$ & $\begin{array}{l}\text { VATS } \\
\text { mediastinoscopy }\end{array}$ & CT-guided biopsy & CT-guided biopsy \\
\hline Histopathology & $\begin{array}{l}\text { positive for CD30, CD68, CD3, CD20, } \\
\text { and LCK }\end{array}$ & positive for CD30, CD15 & positive for CD30, CD15 \\
\hline Diagnosis & $\begin{array}{l}\text { nodular sclerosing type Hodgkin } \\
\text { lymphoma }\end{array}$ & $\begin{array}{l}\text { nodular sclerosing type Hodgkin } \\
\text { lymphoma }\end{array}$ & $\begin{array}{l}\text { nodular sclerosing type } \\
\text { Hodgkin lymphoma }\end{array}$ \\
\hline
\end{tabular}

